\title{
Review of Thomas Piketty's Capital and Ideology. Trans- lated by Arthur Goldhammer. Cambridge, MA: The Belknap Press of Harvard University Press, 2020, 1093 pp.
}

\author{
FRANCESCO GUALA \\ University of Milan
}

\section{PikeTTY’s JuST Society}

Six years ago, the translation of Capital in the Twenty-First Century (Piketty 2014) came out in bookstores all over the world. It would quickly become one of the publishing phenomena of the decade, selling millions of copies and receiving endorsements by celebrities, politicians, and Nobel laureates. In spite of its size (about a thousand pages), Capital in the Twenty-First Century was an interesting example of social science accessible to the average reader. Using dozens of graphs and very little theory, Piketty put forward and defended a simple thesis: after a period of decline in the middle of the twentieth century, inequality in the accumulation of capital has started to rise again, and will continue to do so in the future.

In the recessive climate that followed the collapse of financial markets, the success of Capital in the Twenty-First Century was not difficult to explain. The main message-inequality has increased a lot-was accompanied by another popular claim: inequality has increased too much, and we must do something about it. Being an essentially factual book, however, Capital in the Twenty-First Century did not argue these latter claims. And it did not indicate what sort of reforms could reduce inequality without affecting well-being or creating other injustices. The numerous articles written by Piketty in magazines and newspapers after the release of the book shed some light on his political orientation, but left several questions unanswered: Why do we want more equality? Which inequalities are unjust, and which ones are not? How much inequality are we willing to tolerate, and when does inequality become excessive? And, if inequality is excessive, what can we do about it?

Seven years later, Piketty has published another ambitious and demanding work. The title-Capital and Ideology-evokes Marx again. And the weight is again impressive: 1,100 pages, in the English edition pub- 
lished by Harvard University Press. Capital and Ideology departs even further from the canons of standard books of economics. It deals not only with economic history, but also with the history of ideas and of institutions and contains a political manifesto for a new 'socialism for the twenty-first century'. And yet again, despite its size and breadth, Capital and Ideology does not fully satisfy readers' curiosities, as I will explain shortly.

First, I will summarize the contents of the book, as far as it is possible. The seventeen chapters of Capital and Ideology are organized in four parts. The first three parts are essentially historical and provide an overview of 'inequality regimes' from the Middle Ages to the present day. By 'regime' Piketty means the set of institutions that determine the production and distribution of wealth in each society. Each regime is partly dependent on the scientific and technological knowledge of the time, without being entirely determined by it. And each regime produces its own 'ideology', that is, a set of beliefs, theories, arguments aimed at justifying the prevalent forms of inequality. Departing from classic Marxism, Piketty emphasizes the autonomy of ideologies from the forms of production. There is no determinism but a relationship of mutual interdependence.

The first three quarters of the book-about seven hundred pagesare only a starter for the main course served in the last part, "Rethinking the Dimensions of Political Conflict" (chapters 14-17). Here Piketty outlines his proposals, a set of reforms aimed at stopping the growth of inequality and creating the conditions for a truly just society. The pivotal mechanism is the wealth tax, a progressive tax on the savings of the richest citizens that would erode the accumulation of capital over the years. The proceeds from the wealth tax would be used to provide a basic starting endowment for young citizens upon reaching the age of maturity. But there is more than this. In the fourth part of the book, Piketty deals with broader issues such as the change in the social base of traditional parties, the emergence of 'nativist' populism, the free movement of individuals across borders, and the problem of global warming.

The main function of the early chapters is preparatory: they are meant to set the stage for Piketty's proposals. The message is simple and not very controversial: the current increase in inequality is not a natural phenomenon and is not inevitable. On the contrary, it is a contingent development that people accept both for lack of imagination (there does not seem to be an alternative) and because they have been persuaded by fallacious arguments. These arguments are precisely the ideology we must 
get rid of. Piketty repeatedly emphasizes that he intends to use the term 'ideology' in a neutral, non-derogatory sense: any regime has its own ideology. This historicist approach, however, cuts both ways, insofar as it suggests a relativist interpretation: If there is no difference in value between different ideologies, if Piketty is describing without passing any judgment, how are we supposed to take his proposal? According to his own approach, he is just producing another ideology. The fact that it is more egalitarian than others does not seem to be a good reason to accept it. Unless...

Unless equality and justice are the same for Piketty, and the goal of designing a more equal society is considered so obvious that it does not even deserve a discussion. This is the impression one gets from reading the first part of Capital and Ideology. 'More equal' and 'more just' are basically used as synonyms, and Piketty never cares to tell us what justice is or why equality is just. We gain some insights only after almost a thousand pages. At this point (968-969), Piketty finally explains that a just society is not characterized by absolute equality. It is rather a society in which inequalities are functional to improve the well-being of those who are worst off. A footnote refers to John Rawls, who articulated this idea in the most comprehensive and influential way half a century ago (Rawls 1971). And this is all the political philosophy that you will find in Capital and Ideology.

This is a serious fault. There is plenty of evidence (for example, Hochschild 1981; Kluegel and Smith 1986; Le Grand 1991; Miller 1992; Konow 2003) that the majority of people do not simply identify justice with equality. They rather think that a just society may well be unequal if the differences are justified. To convince the average citizen, therefore, one cannot appeal to justice in a generic way. A positive argument in favor of more extensive appropriation and redistribution of income by the state is required. The problem today is not mainly to convince voters that it is possible to reduce inequality, as Piketty obstinately argues for a thousand pages. You must convince them that it is right.

Common sense morality in the economic realm is based on two fundamental principles-the principle of equality and the principle of merit or productivity (for example, Mitchell and Tetlock 2009). The first one says that a commodity or service which has not been produced by anyone in particular ought to be distributed equally. The second one says that whoever has produced a good or service has a special entitlement, a right to use, or a priority of ownership over those who have done nothing. The 
problem is how to solve the numerous cases in which the two principles are in conflict-when wealth is produced through cooperation, for example.

Rawls prioritized the principle of equality and believed that the principle of productivity should be violated in order to achieve more equality. The only reason for respecting productivity is that it may work as an incentive for the most talented or industrious members of society. If he had to give up most of his earnings, for example, Lionel Messi might put less effort in training, and in the end might produce football of a lower quality. Similarly, a very talented surgeon with an ordinary salary might prefer to spend the weekends with his family, rather than in the operating room. One of the problems with this approach, noticed by Rawls' critics, is that it seems to assume that inequality is acceptable only as a necessary evil. But most people disagree: they think that it is right for a surgeon to earn more than his colleagues, if he is better at his job and works harder than they do.

One may try to circumvent the problem by linking economic justice directly with commitment, talent, or merit. Equality would then become a relative principle: it would not prescribe the same income for everyone, but the same income for those who have the same merit. Piketty, however, does not like this solution: he dismisses 'meritocratic hypocrisy' in a few paragraphs, as an ideology that has been created merely to justify the position of the winners. Questions of consistency aside (is 'ideology' derogatory now?), he is probably right not to follow this argumentative route. Three decades of philosophical debates have demonstrated that egalitarian theories based on merit-such as Arneson's (1989), Dworkin's (2002), or Roemer's (1998) 'luck egalitarianism', for example-suffer from numerous problems. On the one hand, desert is not aligned with the productivity principle, for success in market economies rewards the ability to satisfy others' preferences, which may depend (and often does depend) on factors that are unrelated to merit, such as luck. On the other hand, trying to compensate for the 'distortions' of luck would raise thorny issues. If he had been born with a single arm, the surgeon would not have been able to operate. Although he does not deserve to have both arms, is this original luck a good reason to take away a chunk of income at the end of the year? If the answer is positive, where are we going to stop? The surgeon was also lucky to have parents who encouraged him to study medicine. He was lucky to have a teacher who inspired him to specialize in surgery instead of geriatrics. He was lucky to be born in a country 
where medical studies are accessible to many. And so on and on, endlessly.

One may say that a precise quantification of merit is not essential. Once we recognize that our individual achievements are largely determined by factors that are beyond our control, we can agree that a significant egalitarian compensation is in order. How much redistribution would be exactly just is a minor detail. But I fear that this reply is wrong, again: it ignores the fact that a significant redistribution of income already takes place and is taken for granted by most citizens. In most European countries, from thirty-five to fifty percent of gross domestic product is taxed and redistributed through direct transfers or via the provision of goods and services (a little less in the United States). The controversial issue is not that we should redistribute, but how much. In all countries most taxation is born by the wealthiest sectors of the population (for example, Joumard, Pisu, and Bloch 2012). In Italy, forty percent of citizens pay almost all income tax, to give an idea, while more than half do not contribute anything (for example, Italian National Institute of Statistics 2017). So, the question is not whether the wealthiest citizens should pay more than others-they already do-but how much more they should pay, compared to the status quo.

This is the key question for Piketty, as indicated by numerous clues. Most notable is his obsession for the highest income bracket, the superrich of the infamous 'one percent'. Statistically, the distribution of the population across income brackets has the shape of an elephant: it begins with a large hump on the left (low and medium-low incomes); it drops in the middle (medium-high incomes); and then rises steeply on the far right (the 'trunk' of the elephant). One of the most significant phenomena of the past thirty years has been the growth of the trunk, that is, the disproportionate increase in the number of families with incomes over two hundred thousand dollars. In relatively dynamic countries, such as the United States, the elephant's hump has also shifted to the right, which means that a significant number of families have made a transition from the middle or lower-middle class to the upper or upper-middle class. But, interestingly, Piketty does not care about the hump-he only looks at the trunk.

Why this obsession? Piketty presumably does not simply hate the rich and is not ideologically anti-capitalist. Although he sometimes presents his proposals as revolutionary, in reality his tax on capital would increase average taxation on wealth to five percent, from current rates of about 
two to three percent. His wealth tax would reach ten percent in the case of large estates, a policy that would progressively erode the accumulation of capital but would not 'transcend' capitalism as Piketty boasts (989).

In my view, his obsession is to be explained differently: Piketty probably senses that the real reason to worry about the super-rich is neither economic nor moral but has to do with the delicate social and political equilibria of democratic countries. Historically, democracy has emerged and has worked well in societies with a strong middle class. The shifts in income described above-the sinking of the elephant's 'hump', in particular-have reduced the political center of gravity upon which democratic countries are based. This is a historic change of great importance, with potentially devastating effects (for example, Fukuyama 2011).

The divergence of interests between classes that differ too much in terms of lifestyle, culture, and the ability to influence political decisions, tends to generate enormous tensions that are difficult to control. In many cases, it promotes social segregation, endemic violence (high crime, private protection agencies), and the emergence of 'strong men' who try to combine nationalistic populism with a defense of the economic interests of the oligarchy.

Those who care about democracy are entitled to worry. Perhaps Piketty is among them, even if he does not say it explicitly. It is a pity that he does not try to articulate his concern for the super-rich more clearly, not the least because some of the arguments are ready to use. 'Democratic egalitarianism' would offer solid arguments in support of his reforms. The main message of democratic egalitarians like Elizabeth Anderson (1999) and David Miller (1999) is that the Left should not pursue equality as an end in itself. The preservation of social cohesion within national communities, without which democracy cannot function, should be the main target of progressive parties. Such a goal does not require that we are able to measure desert, because it has little to do with it. Nor does it require that we identify justice with equality in the economic sense. Freedom and political justice, primarily, require that we impose a cap on excessive inequality.

I have dwelled on these issues because the main shortcoming of Piketty's book is the lack of an underlying theory. Capital in the TwentyFirst Century was a factual book, and this theoretical deficit could be forgiven. But Capital and Ideology is explicitly a political text: those who expected a theoretical leap, unfortunately, will be disappointed. 
We still have Piketty's recipes for reform, of course: from this point of view, what is the overall verdict? Piketty has the great skill of simplifying complex arguments using large numbers. The sections dedicated to the tax on accumulated wealth are convincing, in the sense that the reader is persuaded that in principle it can be done. For income tax, Piketty revives the top brackets of the Old Left. The proceeds would be used to finance a form of minimum income, as many representatives of the New Left advocate. But above all, they would promote inter-generational redistribution and partially neutralize hereditary privilege. These reforms would allow to bridge the gap, both in income and in opportunities, between younger and older people which in many countries continues to increase over time. Finally, a more robust participation of workers in the management of large firms-modelled on German and Swedish corporate law-would impose natural limitations on managers' salaries.

Piketty does not spend much time discussing the obstacles that such reforms would face. Aversion to taxation in many societies is correlated with lack of trust in state institutions. Unfortunately, Piketty always plays the role of advisor to an enlightened prince or citizenship, who once persuaded would have no problem applying the just reforms. In the ideal world of Piketty, the government is always benevolent. Citizens trust politicians and do not punish them when they raise taxation. Unions never defend unproductive rent and never lead companies to bankruptcy with the collusion of politicians. The rich are the source of all evil, and if we get rid of them, everything will be fine.

Things are a little more complicated, as politicians know well. Citizens do not trust governments blindly, even when the latter try to defend the rights of the poor. Citizens often do not trust each other and fear that transfers of resources will turn into rents. Such hurdles would be even more impervious if the redistribution of resources took place on a global scale. Piketty is in favor of transgressing national borders, both in the movement of people and in fiscal solidarity. But in his idealized world, citizens have no qualms about giving up part of their sovereignty. Hungarian or Spanish voters are willing to be governed by a Dutch or Finnish prime minister, and when the latter imposes sacrifices or spending cuts, they accept them cheerfully. European elections are held in this fictional world even if candidates are unable to address their voters in an understandable language. Finally, in the world of Piketty, populists cannot exploit people's resentment against foreigners to gain seats in parliament. 
I suspect that political scientists will find the chapters devoted to trans-national justice, populism, and global warming rather naive. It is a pity because Capital and Ideology is full of interesting ideas. The problem is that the analysis of economic reforms-in particular, of the tax policies-does not justify a volume of over a thousand pages. Piketty should have written a more compact book centered on the last chapter, perhaps introduced by a short summary of the previous ones. The great historical fresco of the first seven hundred pages deserves a separate outlet and does not add much to Piketty's theses. An explicit defense of the idea of justice underlying the reforms, on the other hand, would have greatly strengthened his political proposal. But for this we will have to wait until the next book, which the prolific Piketty will undoubtedly write soon.

\section{REFERENCES}

Anderson, Elizabeth S. 1999. "What Is the Point of Equality?" Ethics 109 (2): 287-337.

Arneson, Richard J. 1989. "Equality and Equal Opportunity for Welfare." Philosophical Studies 56 (1): 77-93.

Dworkin, Ronald. 2002. Sovereign Virtue: The Theory and Practice of Equality. Cambridge, MA: Harvard University Press.

Fukuyama, Francis. 2011. "Poverty, Inequality, and Democracy: Dealing with Inequality." Journal of Democracy 22 (3): 79-89.

Guala, Francesco. 2018. "Piketty e L'uguaglianza." Doppiozero. Published on February 22, 2018. https://www.doppiozero.com/materiali/piketty-e-luguaglianza.

Hochschild, Jennifer L. 1981. What's Fair? American Beliefs about Distributive Justice. Cambridge, MA: Harvard University Press.

Italian National Institute of Statistics. 2017. "La Redistribuzione del Reddito in Italia." Press release No. 201597, June 21, 2017. https://www.istat.it/it/files/2017/06/CS_Redistribuzione-reddito-in-Italia_2016.pdf.

Joumard, Isabelle, Mauro Pisu, and Debbie Bloch. 2012. “Tackling Income Inequality: The Role of Taxes and Transfers". OECD Journal: Economic Studies 2012 (1): 37-70.

Kluegel, James R., and Eliot R. Smith. 1986. Beliefs about Inequality: Americans' Views of What Is and What Ought to Be. New York, NY: Aldine De Gruyter.

Konow, James. 2003. "Which Is the Fairest One of All? A Positive Analysis of Justice Theories." Journal of Economic Literature 41 (4): 1188-1239.

Le Grand, Julian. 1991. Equity and Choice: An Essay in Economics and Applied Philosophy. London: Routledge.

Miller, David. 1992. "Distributive Justice: What the People Think." Ethics 102 (3): 555593.

Miller, David. 1999. Principles of Social Justice. Cambridge, MA: Harvard University Press. Mitchell, Gregory, and Philip E. Tetlock. 2009. "Disentangling Reasons and Rationalizations: Exploring Perceived Fairness in Hypothetical Societies." In Social and Psychological Bases of Ideology and System Justification, edited by John T. Jost, Aaron C. Kay, and Hulda Thorisdottir, 126-157. New York, NY: Oxford University Press. 
Piketty, Thomas. 2014. Capital in the Twenty-First Century. Translated by Arthur Goldhammer. Cambridge, MA: The Belknap Press of Harvard University Press.

Rawls, John. 1971. A Theory of Justice. Cambridge, MA: The Belknap Press of Harvard University Press.

Roemer, John E. 1998. Equality of Opportunity. Cambridge, MA: Harvard University Press.

Francesco Guala is a philosopher and experimental economist interested primarily in the foundations and the methodology of social science. He teaches in the Department of Philosophy at the University of Milan (Italy). He is the author of many articles in scientific and philosophical journals, and of two monographs, The Methodology of Experimental Economics (Cambridge, 2005) and Understanding Institutions (Princeton, 2016). In 2011 he co-edited with Daniel Steel The Philosophy of Social Science Reader (Routledge).

Contact e-mail: <francesco.guala@unimi.it>

Website: <users.unimi.it/guala> 